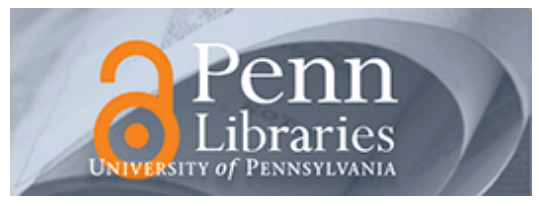

University of Pennsylvania

ScholarlyCommons

Management Papers

Wharton Faculty Research

$5-1996$

\title{
Wages and Foreign Ownership: A Comparative Study of Mexico, Venezuela, and the United States
}

Brian J. Aitken

Ann E. Harrison

University of Pennsylvania

Robert E. Lipsey

Follow this and additional works at: https://repository.upenn.edu/mgmt_papers

Part of the Business Administration, Management, and Operations Commons, and the International Business Commons

\section{Recommended Citation}

Aitken, B. J., Harrison, A. E., \& Lipsey, R. E. (1996). Wages and Foreign Ownership: A Comparative Study of Mexico, Venezuela, and the United States. Journal of International Economics, 40 (3-4), 345-371.

http://dx.doi.org/10.1016/0022-1996(95)01410-1

This paper is posted at ScholarlyCommons. https://repository.upenn.edu/mgmt_papers/9

For more information, please contact repository@pobox.upenn.edu. 


\title{
Wages and Foreign Ownership: A Comparative Study of Mexico, Venezuela, and the United States
}

\author{
Abstract \\ This paper explores the relationship between wages and foreign investment in Mexico, Venezuela, and the \\ United States. Despite very different economic conditions and levels of development, we find one fact \\ that is robust across all three countries: higher levels of foreign investment are associated with higher \\ wages. However, in Mexico and Venezuela, foreign investment is associated with higher wages only for \\ foreign-owned firms - there is no evidence of wage spillovers leading to higher wages for domestic firms. \\ The lack of spillovers in Mexico and Venezuela is consistent with significant wage differentials between \\ foreign and domestic enterprises. In the United States, where the evidence suggests some wage \\ spillovers from foreign to domestic enterprises, wage differentials are smaller.

\section{Disciplines} \\ Business Administration, Management, and Operations | International Business
}




\section{WAGES AND FOREIGN OWNERSHIP: A COMPARATIVE STUDY OF MEXICO, VENEZUELA, AND THE UNITED STATES}

Brian Aitken

Ann Harrison

Robert E. Lipsey

Working Paper No. 5102

\section{NATIONAL BUREAU OF ECONOMIC RESEARCH 1050 Massachusetts Avenue Cambridge, MA 02138 \\ May 1995}

We would like to thank Mukul Kumar and Sherry Zhang for excellent research assistance. We would also like to thank Robert Baldwin, Phil Swagel, and participants at the NBER October 1994 meeting for helpful comments and suggestions. This paper is part of NBER's research program in International Trade and Investment. Any opinions expressed are those of the authors and not those of the National Bureau of Economic Research.

(C) 1995 by Brian Aitken, Ann Harrison and Robert E. Lipsey. All rights reserved. Short sections of ext, not to exceed two paragraphs, may be quoted without explicit permission provided that full credit, including $\odot$ notice, is given to the source. 


\title{
WAGES AND FOREIGN OWNERSHIP: A COMPARATIVE STUDY OF MEXICO, VENEZUELA, AND THE UNITED STATES
}

\begin{abstract}
This paper explores the relationship between wages and foreign investment in Mexico, Venezuela, and the United States. Despite very different economic conditions and levels of development, we find one fact which is robust across all three countries: higher levels of foreign investment are associated with higher wages. In Mexico and Venezuela, foreign investment was associated with higher wages only for foreign-owned firms -- there is no evidence of wage spillovers leading to higher wages for domestic firms. In the United States there is evidence of wage spillovers.
\end{abstract}

The lack of spillovers in Mexico and Venezuela is consistent with significant wage differentials between foreign and domestic enterprises. In the United States, wage differentials are smaller.

Brian Aitken

International Monetary Fund

700 19th Street, NW

Washington, DC 20431
Ann Harrison

School of Business

Columbia University

615 Uris Hall

New York, NY 10027

and NBER
Robert E. Lipsey

National Bureau of

Economic Research

269 Mercer Street

8th Floor

New York, NY 10003 and NBER 


\section{Introduction}

Recent developments in growth theory emphasize the important role played by human capital formation. Although human capital is acquired through formal schooling, research and development, or even international trade, Lucas (1993) argues that on-the-job training is by far the most important avenue. In particular, he shows that on-the-job training is associated with rapid growth when the labor force moves quickly into more and more productive activities. This is the so-called "quality ladder", described in Grossman and Helpman (1991a, 1991b).

Apart from scattered case studies (see, example, the steep learning curves in Liberty Ship production described in Lucas (1993)), empirical evidence on the linkages between human capital formation, on-the-job training, and economic growth is limited. In this respect, micro-level evidence on multinational enterprises could be quite useful. Since foreign direct investment presumably represents a transfer of technology or ideas to the host country, it provides an opportunity to empirically identify the linkages between human capital formation, on-the-job training, and productivity growth. Entry by foreign multinationals provides the host country with access to knowledge. This access is enhanced if the foreign investor's knowledge is absorbed by domestic workers, increasing the domestic stock of human capital and making the local labor force permanently more productive. Moreover, foreign direct investment can facilitate the spread of knowledge to domestically-owned firms, either directly through, for example, the training of suppliers, or indirectly through imitation and labor mobility.

Beyond its contribution to human capital through on-the-job training, foreign direct investment can play an important role by facilitating the flow of ideas across national borders. Indeed, Romer (1993) refers to the "idea gap" to describe differences in the utilization of productive knowledge across countries, as opposed to the differences in physical capital and levels of education, or the "object gap". Romer argues that cross-country data and other evidence support the claim that a country's growth performance has as much to do with its utilization of ideas embodied in foreign direct investment as with the 
accumulation of capital or the extent of secondary-school enrollment. While Romer emphasizes the spread of knowledge from developed to developing countries, this does not preclude idea gaps from existing in certain industries between countries of equal development. The relevant question is whether foreign direct investment contributes to growth by filling idea gaps that exist between countries, whether developing or developed.

Evidence that multinational firms play a significant role in "catch up" can be examined by measuring the impact of foreign direct investment (FDl) on domestic wages. If multinationals bring ideas to the host country, foreign investors should put upward pressure on wages as the marginal productivity of workers in those plants rises. If this productivity advantage is significant, equilibrium wages should rise in response to increases in FDI. If, however, FDI affects labor demand in the same way as domestic investment, the role of foreign direct investors in transmitting productive knowledge is limited.

This paper measures the impact of foreign direct investment on wages in the United States, Mexico, and Venezuela, drawing implications for the role of foreign investors in the transmission of knowledge and the formation of human capital. We find in Section II that, in all three countries, wages are higher where foreign-owned production is greater. However, in the case of Mexico and Venezuela, the higher overall wage is due to higher wages only in foreign-owned firms--there are no positive wage spillovers to domestic enterprises. Section III examines the implications of this evidence, along with evidence on wage differences between foreign and domestic firms, for the accumulation of human capital and the spread of knowledge to domestic firms.

\section{Testing for Wage Spillovers}

\section{Foreign Direct Investment and the Spread of Intangible Assets}

Foreign direct investors in a country presumably have access to productive knowledge not available to host-country domestic producers. The "industrial organization" approach to foreign direct 
investment suggests that multinational firms can compete locally with domestic firms only because multinational firms possess intangible productive assets such as technological know-how, marketing and managing skills, export contacts, coordinated relationships with suppliers and customers, and reputation. ${ }^{1}$ Often the intangibility of these assets makes them much less costly to transfer to subsidiaries in a host economy than to license at arm's length to host country firms. Direct investment is the manner in which the multinational firm overcomes the market imperfections related to the sale of intangible productive assets.

Data restrictions make it difficult to test directly whether in fact foreign ownership carries any productive advantage. While it is usually the case that foreign firms exhibit higher labor productivity than domestic firms, they also tend to congregate in capital intensive industries and, particularly in developing countries, in regions with more advanced infrastructure. In one of the few statistical tests of the issue, Aitken and Harrison (1993) find that for Venezuelan manufacturing plants, after controlling for capital stock and factors affecting productivity such as size, industry and location, higher foreign equity participation is strongly correlated with higher plant total factor productivity.

Even if foreign investors bring their productive advantage to the host economy, it is far from evident that foreign firms play a quantitatively significant role in the spread of productive knowledge to domestic firms. There is no doubt that foreign investors often can facilitate the spread of productive knowledge; numerous case studies illustrate the channels through which foreign investors have improved the performance of domestic firms, including improved access to technology, management and marketing practices, and buyer-seller linkages in foreign markets. ${ }^{2}$ In addition, foreign firms typically show a investment.

1 See Caves (1982) and Helleiner (1989) for surveys on technology and foreign direct

${ }^{2}$ See Rhee and Belot (1989), Mody et al. (1991) for recent case studies. 
stronger commitment to technical and managerial training, particularly for skilled workers. ${ }^{3}$

However, the empirical evidence on the overall impact of foreign firms in the diffusion of knowledge remains mixed. In support of an important role for foreign firms as export catalysts, Aitken, Hanson, and Harrison (1994) find that Mexican manufacturing firms were significantly more likely to export when foreign firms were located nearby. Caves (1974) and Globerman (1979) found that domestic firms in sectors with greater foreign ownership were more productive. This result was confirmed in the case of Mexico in a series of studies summarized in Blomström (1989). Aitken and Harrison (1993) however, found that this relationship disappeared in Venezuela after controlling for the fact that foreign investment is concentrated in more productive industries; while foreign investment raises productivity overall, the gains are internalized or captured by other foreign firms, with productivity in domestic firms actually declining. This result is consistent with a 1970's OECD study of 65 subsidiaries in twelve developing countries which found little evidence of spillovers to domestic firms. The study attributed this finding to a number of factors, including limited hiring of higher-level domestic employees, very little labor mobility between foreign and domestic firms, limited domestic subcontracting, and few incentives for multinationals to diffuse knowledge to local competitors (Germidis, 1977).

Modelling Framework The impact of multinational firms' wages can be interpreted in a standard supply and demand framework for labor. Given the local supply of labor, the demand schedule will be represented by the marginal product of labor derived from the aggregate production function for all firms--domestically- and foreign-owned--producing in the local labor market. If foreign-owned firms have a productive advantage over their domestically-owned counterparts, an increase in foreign presence in the labor market--all else equal--will raise productivity, thereby raising labor demand for a given set of factors. Provided the labor supply curve in the local labor market is upward sloping, the result will be an increase in the equilibrium wage.

\footnotetext{
${ }^{3}$ See Reuber p.202, Goncalves (1986).
} 
More explicitly, we start with a production function for a given location and industry given by

$$
Y=A(D F I) f(X, L)
$$

where DFI is the share of labor in the market employed by foreign firms and serves as a proxy for foreign presence in the industry and region, $\mathrm{L}$ is the labor employed by the industry, and $\mathrm{X}$ includes all other factors of production. Equilibrium in this labor market is achieved when

$$
\begin{aligned}
W & =\text { PRICE* }^{*} P_{L} \\
& =\text { PRICE* }
\end{aligned}
$$

where $\mathrm{W}$ is the wage, and $\mathrm{L}(\mathrm{W})$ denotes the labor supply curve.

The hypothesis that we test is that foreign-owned firms raise the overall marginal productivity of labor. To test this, we regress wages in a given location and industry on foreign presence, controlling for other factors which affect wages or overall labor demand. Log-linearizing equation (2) yields

$$
\log \mathrm{W}=\mathrm{C}+\alpha_{1} \mathrm{DFI}+\alpha_{2} \log \mathrm{PRICE}+\alpha_{3} \log \mathrm{X}-\alpha_{4}(v \log \mathrm{W})
$$

where $v$ is the elasticity of labor supply. We estimate the reduced form of equation (3), which becomes

$$
\log \mathrm{W}=1 /\left(1+\alpha_{4} v\right)\left[\mathrm{C}+\alpha_{1} \mathrm{DFI}+\alpha_{2} \log \mathrm{PRICE}+\alpha_{3} \log \mathrm{X}\right]
$$

If foreign investors bring with them knowledge that raises average productivity, then $\alpha_{1}$ will be greater than zero and, provided the labor supply curve is not perfectly elastic, wages will increase with foreign investment. It is important to note that since 
(5) $\alpha_{1}>1 /\left(1+\alpha_{4} v\right)$

the coefficient on foreign share which we estimate from the reduced form equation will serve as a lower bound for the actual impact of foreign investment on productivity. Estimates will substantially understate the true impact if labor mobility between industries and regions is significant, resulting in more elastic labor supply.

The data for Venezuela, Mexico, and the United States used here are all from production censuses. However, individual plant data were available for Venezuela and Mexico, but not for the United States, for which only a state by industry breakdown was possible. The definition of foreignowned in the U.S. data was ownership of 10 per cent or more of equity in the enterprise owning an establishment by a foreign resident, and all employees of such establishments were classified as employed by foreign-owned firms. The definition of foreign-owned in the Venezuelan and Mexican data was ownership of any equity in the enterprise by foreign residents, but workers in each establishment were then allocated between foreign and domestic ownership according to the shares in equity. In addition, the United States data did not begin to become available until 1987, and are therefore used here only in cross-sectional form, while the data for Venezuela cover the period 1977 through 1989 and those for Mexico 1984 through 1990, thus providing variation over time as well as geographically within each country.

In the time-series-cross-section estimation results presented below for Venezuela and Mexico, wage equations for skilled and unskilled workers are reported separately. Other controls include capital stock (KSTOCK), royalty payments (ROYALTY) which proxy for industry-specific acquisition of technology, an industry dummy (SIC), and a region dummy (LOC) which captures various location specific factors such as the human capital of the labor force, agglomeration, and infrastructure. To avoid endogeneity problems, KSTOCK is lagged one period. DFI is measured as the share of labor employed 
by foreign-owned firms in the industry (SIC) and region, while e is a random shock. This yields the two estimating equations:

$$
\begin{aligned}
& \log _{\mathrm{ak}}=\alpha_{0}+\alpha_{1} \text { DFI }+\alpha_{2} \log \text { PICE }+\alpha_{3} \text { ROYALTY }+\alpha_{4} \text { KSTOCK } \\
& +\mathrm{LOC}+\mathrm{SIC}+\mathrm{e} \\
& \mathrm{LogW}_{\text {usk }}=\mathrm{B}_{0}+\mathrm{B}_{1} \mathrm{DFI}+\mathrm{B}_{2} \log \mathrm{PRICE}+\mathrm{B}_{3} \text { ROYALTY }+\mathrm{B}_{4} \text { KSTOCK } \\
& +\mathrm{LOC}+\mathrm{SIC}+\mathrm{e}
\end{aligned}
$$

If the coefficient on foreign share, $\alpha_{1}$ or $B_{1}$, is positive, then increases in foreign presence increase wages in the region, after accounting for the increases in capital stock which could accompany the foreign investment and could independently lead to wage increases. If foreign firms "steal" the best domestic workers or only invest in the most productive or highest paying domestic firms, increases in DFI should be uncorrelated with $\log W$, since the overall pool of labor has not changed, and $\alpha_{1}$ and $B_{1}$ should be zero. If foreign firms only invest in regions or industries that pay higher wages, then $\alpha_{1}$ and $B_{1}$ would be zero since SIC and LOC are included in the regression.

Empirical Results The estimation results for Venezuela and Mexico are reported in Table 1. The dependent variable is the log of average wages by four-digit industry and district. Both a producer price (at the four-digit level) and a region CPI are included in the estimation for Venezuela, but are not available for Mexico. Capital stock is in $\log$ form, defined as the reported capital stock at the firm-level, adjusted for inflation and aggregated up to the industry and district level.

The first four columns of Table 1 report the impact of foreign investment in Venezuela, where foreign investment is measured as the share of employment in enterprises with foreign equity investment at the region-district level. The first two columns report the impact of foreign investment on aggregate wages for both foreign and domestic enterprises combined. For both skilled and unskilled workers, a higher share of foreign employment raises overall wages. The impact is similar across both skill groups. 
The coefficient, which varies from 0.22 (for unskilled workers) to 0.29 (for skilled workers), suggests that a 10 per cent increase in the share of foreign investment in overall employment in a region and industry would raise wages by 2.2 to 2.9 per cent. The results also suggest that payments for royalties, which proxies for acquisition of technology, are highly correlated with wages. An increase in the share of royalty payments in sales from 0 to 1 per cent would increase wages between .7 and 2.1 per cent.

The next two columns of Table 1 report the relationship between foreign investment and wages for domestic enterprises only-enterprises with no foreign equity share. The results suggest that in Venezuela there are no positive wages spillovers from foreign investment to domestically owned enterprises. In fact, the wage effects appear to be negative. The negative impact is likely to be due to a combination of two factors. First, to the extent that foreign enterprises poach on domestic competitors, selecting the best workers, this could account for the observed negative coefficient on DFI. Second, as we show in Aitken and Harrison (1993), increased foreign competition has been associated with declining domestic productivity in Venezuela, which is reflected here in lower wages. Although the net impact of more foreign investment is positive, as shown in the first two columns, all the benefits are concentrated in firms with foreign equity. These results are consistent across skilled and unskilled workers.

The results using the same specification for Mexico are reported in the last four columns of Table 1. For Mexico, only the output price is included in the estimation, since a regional price deflator was not available. The first two columns for Mexico, which report the impact of foreign investment on overall wages, are generally consistent with the Venezuelan results. A ten per cent higher share of foreign firm employment would be associated with skilled wages 2.2 per cent higher. However, the positive impact of foreign investment is significantly lower for unskilled workers than for skilled employees.

The last two columns report the impact of foreign investment in Mexico on wages for domestic enterprises only. The results suggest that foreign investment had either no impact or a slightly negative 
(but statistically insignificant) impact on domestic skilled and unskilled wages. In the Mexican case, the results are consistent with Venezuela in pointing to no spillovers from foreign investment to wages in domestic enterprises.

Could the negative or zero impact of foreign investment on wages in domestic enterprises reflect "poaching" by foreign enterprises? If foreign enterprises simply steal away the best workers from domestic enterprises, more foreign investment will be associated with higher wages in joint ventures and lower wages in domestic enterprises. The same would be true if higher wages in foreign enterprises reflected worker heterogeneity and not human capital formation. Yet if foreign investment had no impact on wages--simply leading to a reallocation of labor towards firms with foreign equity--the impact of DFI on aggregate wages would be zero. It is clear from Table 1 that higher foreign investment is associated with higher wages for the labor force as a whole.

Another possible objection could be raised about the exogeneity of foreign investment. To the extent that foreign investment is attracted to sectors or regions where wages are higher or rising (or falling), we could be over (or under) estimating the impact of foreign investment on wages. Table 2 reports two-stage least squares (2SLS) estimates for Venezuela and Mexico. In addition to the other exogenous right-hand side variables in equations (6) and (7), we added two sets of instruments for foreign investment. The first set was drawn from the NBER manufacturing database, which reports average wages by sector over time. We included both the average (real) wage by sector and year, as well as the labor share in both value-added and output as instruments. The rationale for using these instruments is based on the fact that one major motivation for foreign investment--particularly into Mexico--is to escape high labor costs at home. Since the United States is the major source of foreign investment in both Mexico and Venezuela, wages for the US would appear to be good instruments for foreign investment in those countries.

The results from the first set of instrumental variables regressions are reported in the first two 
columns of Table 2. In the last two columns, three additional instruments were also included. The first instrument is the distribution of foreign investment in Mexico (for Venezuela), or the distribution in Venezuela (for Mexico). Although the sectoral distribution of foreign investment in Venezuela should be uncorrelated with wages in Mexico, it is likely to be correlated with the pattern of foreign investment in Mexico. The two other instruments include (1) import penetration, which is positively correlated with foreign investment in both countries and (2) the concentration of foreign investment in the region, defined as the sales-weighted share of foreign equity for all other industries within the region. This last instrument captures the fact that foreign investors are often drawn to regions where there is already a significant foreign presence.

The results in Table 2 are comparable to the OLS results reported earlier, particularly for Mexico where the point estimates change only slightly. For Venezuela, the pattern is also the same, with a negative impact of foreign investment on wages for domestically-owned enterprises, but an overall positive impact when both domestic and foreign enterprises are included. The only major difference is that the 2SLS point estimates for Venezuela are much higher than for the OLS estimation. The results suggest that a 10 per cent increase in the share of foreign investment would lead (for all enterprises) to a 20 and 70 per cent increase in wages. These magnitudes seem quite large, suggesting that the OLS results are more plausible than the 2SLS estimates.

The impact of foreign investment on US wages is presented in Table 3. As mentioned above, the results in Table 3 exploit only the geographical and industry variation in foreign investment and wages. State and industry effects on wage levels are represented not by dummy variables, as for Venezuela and Mexico, but by quantitative variables. For state effects, these are averages across detailed industries of state wages relative to national wages. For industry effects, they are averages across states of industry wages relative to state wages. The average wage in an industry in a state was regressed on DFI and the two control variables for industry and state wage levels. As in Venezuela and Mexico, the 
higher the share of employment in foreign-owned firms, the higher the average wage, after taking account of state and industry wage effects. A very different picture emerges, however, for wages in domesticallyowned plants. In the United States, a larger share of foreign firms in employment is associated with higher wages in both foreign and domestic establishments. Thus, in the United States, the evidence is consistent with positive spillovers from foreign investment to domestic wages. These results provide a direct contrast to the lack of spillovers in Venezuela and Mexico, where it appears that all the positive wage effects of foreign investment are concentrated in foreign enterprises.

Explanations for the Presence and Absence of Wage Spillovers The absence of spillovers from DFI to domestic wages in Venezuela and Mexico could be due to many factors. One explanation is that foreign firms incur higher search costs than domestic enterprises who are familiar with the local labor market, leading foreign enterprises to seek ways to discourage turnover once a worker joins the firm. One way to inhibit turnover is to pay higher wages. Foreign firms may also invest more in worker training, which would also lead them to pay high wages as a means of inhibiting turnover. Another possibility is that the ability to absorb new technology in Mexico and Venezuela is much more limited than in the United States. It is likely that domestic firms in Venezuela and Mexico are much less able to absorb new technology than domestic firms in the United States because of the lower level of managerial and technical skills in the Venezuelan and Mexican domestic firms. For example, Eaton and Kortum (1994) emphasize the ability to absorb technology as an important factor in explaining patenting, while Kokko (1994) points to a greater probability of technology spillovers from foreign firms in more advanced domestic sectors.

Another possibility is that foreign enterprises in developing countries have less bargaining power vis-à-vis labor unions than domestic firms, or are more likely to adhere to legislation mandating minimum wages, overtime pay and other benefits. This hypothesis implies that wage differentials between foreign and domestic enterprises, as well as the lack of spillovers, are due purely to institutional factors, instead 
of productivity differences. The wage efficiency hypothesis also implies that wage differences are not necessarily due to productivity, particularly if foreign enterprises have more reason to discourage turnover. Below, we examine the productivity performance of foreign and domestic enterprises. The results suggest that productivity patterns are quite consistent with the wage patterns described above, casting doubt on the institutional and search costs explanations.

Evidence on productivity differences between foreign and domestic enterprises in developing countries is reported in Aitken and Harrison (1993) for Venezuela, in Haddad and Harrison (1992) for Morocco, in Harrison (1993) for Cote d'Ivoire, and in Luttmer and Oks (1993) for Mexico. All these studies find that foreign enterprises have higher levels of labor and total factor productivity, although the evidence on growth rates of productivity is more mixed. In addition, Harrison (1993) reports wage and labor productivity comparisons across foreign and domestic enterprises by sector for the lvory Coast, Morocco, and Venezuela. For all three countries, the cross-sector correlation between higher productivity and higher wage differentials between domestic and foreign enterprises is striking.

The results in Tables 1 and 2 pointed to a positive relationship between wages and the foreign share of employment for all establishments, but a negative relationship between foreign investment and wages in domestically-owned establishments, at least for Venezuela and possibly (to a lesser extent), for Mexico. If the observed wage differentials between foreign and domestic enterprises can be explained by productivity differentials, the positive wage impact of foreign investment on remuneration in joint ventures and the negative spillover for domestic competitors should translate into a productivity impact which is positive for joint ventures and negative for domestic competitors. This is exactly what both Aitken and Harrison (1993) find for Venezuela and Luttmer and Oks (1993) find for Mexico. Foreign investment is associated with higher productivity for those enterprises that receive the foreign investment, but with lower productivity in other firms. This suggests that the observed wage differentials are entirely consistent with the productivity story. It appears that in Mexico and Venezuela, the gains from foreign 
investment--higher productivity and higher wages--were internalized by the foreign-owned firms.

For the United States, data comparing foreign and domestic firms at the establishment level have only recently become available. ${ }^{4}$ A simple comparison of value added per employee between foreignowned and domestically-owned establishments, for 1988, 1990, and 1991, weighting by total employment in each industry, shows a margin of roughly 10 per cent in favor of foreign-owned establishments (Lipsey, 1995, Table 27). A comparison for 1987 of shipments per employee, weighting observations by total employment in each industry in each state, shows that for this measure, at least (value added is not available), the inclusion of the geographical control almost doubles the difference between foreignowned and domestically-owned establishments in manufacturing industries, (Lipsey, 1995, Table 26). The effect of the geographic control was smaller for nonmanufacturing industries.

The differences in value added per employee are smaller than those in shipments per employee. If they incorporate the same bias from ignoring state differences they could reflect substantial productivity margins in favor of the foreign-owned establishments, but even if there were no bias, the data indicate a labor productivity differential of almost 10 per cent. This productivity differential is surprisingly similar to the wage differentials between foreign and domestic enterprises for the United States reported in Section III.

One explanation for higher value added per worker in foreign-owned plants might be that the capital input per worker is higher. We do not have capital stock data but if we are willing to take

4 Ideally, we would like to use the same breakdown of data as for the analysis of wage rates to ask whether the presence or growth of foreign-owned establishments affects labor productivity or changes in productivity. Unfortunately, the data relating to productivity that are divided between foreign-owned and domestically-owned establishments are more limited than those relating to wages. Data on value added per employee, which we use as a proxy for productivity, are not available for 1987, and those for later years are confined to manufacturing and do not incorporate a geographical breakdown. Furthermore, they are subject to manipulation for minimization of taxes, and while there are undoubtedly some such valuation problems within domestically-owned firms, the opportunities for tax saving may be greater when intrafirm transactions cross national borders. We also lack an adequate time span over which to observe changes in productivity, and we lack information on capital input that might help to explain levels of and changes in labor productivity. 
nonwage value added as a proxy for payments to owners of capital, we can make a comparison. It shows that nonwage value added per worker was, on average, 14 per cent higher in foreign-owned establishments than in domestically-owned establishments within industries. Thus, the higher labor productivity suggested by the higher value added per worker seems to be associated with higher capital intensity in foreign-owned establishments. That relationship is confirmed by the fact that, across the 105 industries, the ratio of value added per worker in foreign-owned establishments to that in domesticallyowned establishments (which we have used as a proxy for relative labor productivity) is almost completely explained by the relative nonwage value added per worker (which we have thought of as a proxy for capital intensity)..$^{s}$

That relationship is not surprising in view of the larger size of the foreign plants, but it could also represent other factors, especially since nonwage value added is about half of total value added and is the part of value added that would be affected by these factors. Foreign-owned plants might be earning higher profits from exploiting their firm-specific technology or other assets, or because they have received concessions from state and local governments, or they may be exaggerating their profits to transfer them to these plants by undervaluing inputs purchased from parents or other affiliated entities. The last of these possibilities does not seem particularly plausible in view of the widespread suspicion that foreign firms are artificially minimizing, rather than maximizing, the share of their profits they report earning in the United States.

Across 105 3-digit U.S. manufacturing industries in 1990 we can analyze the relation between

5 This statement is based on the results of the following regression:

$$
\mathrm{VAE}(\mathrm{F} / \mathrm{D})=.383+.628 \mathrm{NWVAE}(\mathrm{F} / \mathrm{D}) \quad \overline{\mathrm{R}}^{2}=.970
$$

where $\mathrm{VAE}(\mathrm{F} / \mathrm{D})=$ Value added per worker, foreign-owned/domestically-owned

NWVAE $(F / D)=$ Nonwage value added per worker, foreign-owned/domestically-owned. 
labor productivity, as proxied by value added per employee, and the extent of foreign ownership, along the lines of the studies for Mexico and Venezuela. Equations 1 and 2 describe this relationship when no control for capital intensity is included:

All establishments
(1) $\mathrm{VAE}=49.61+236.40 \mathrm{FES}$
$\overline{\mathrm{R}}^{2}=.251$

(7.48)

(6.01)

Domestically-owned Establishments

(2) $\mathrm{VAE}=\underset{(7.05)}{4} \begin{gathered}49.27 \\ (41.47)\end{gathered}+\underset{\mathrm{R}^{2}}{232.63 \mathrm{FES}} .225$

$$
\begin{aligned}
& \text { where VAE }=\text { Value added per employee }(\$ 000) \\
& \qquad \text { FES }=\text { Share of employment in foreign-owned establishments } \\
& \text { t statistics in parentheses. }
\end{aligned}
$$

Since value added per employee is closely related to capital intensity, we add nonwage value added per employee as a proxy for capital intensity in equations 3 and 4 .

All establishments

$$
\text { (3) } \mathrm{VAE}=\underset{(22.63)}{20.07}+\underset{(2.33)}{12.84 \mathrm{FES}}+\underset{(82.69)}{1.086 \mathrm{NWVAE}} \quad \overline{\mathrm{R}}^{2}=.989
$$

Domestically-owned establishments

$$
\text { (4) } \mathrm{VAE}=\underset{(22.59)}{20.21}+\underset{(2.40)}{13.30 \mathrm{FES}}+\underset{(85.56)}{1.080 \mathrm{NWVAE}}+\overline{\mathrm{R}}^{2}=.989
$$

As in Mexico and Venezuela, a higher foreign presence in an industry is associated with higher productivity for the industry as a whole. In contrast to the relationship in those two countries, higher foreign presence in an industry in the United States is associated with higher productivity in domestic establishments, a relationship that is in accord with the fact that higher foreign presence in a U.S. industry is also associated with higher wages in domestically-owned establishments. Thus, the productivity data and the wage data for the United States suggest spillovers from foreign-owned to 
domestically-owned establishments that are not visible in Mexico and Venezuela.

Another hint of a productivity effect of foreign ownership can be drawn from an examination of changes in 1991 for U.S. affiliates newly acquired by foreign firms in 1990 . If these are compared with existing affiliates, by industry, sales per employee in the newly acquired affiliates increased relative to those in the existing affiliates. That increase in the sales per employee involved a reduction in employment by the new affiliates in most, though not all, industries, while existing affiliates in most industries increased employment (Lipsey, 1995, Tables 21 and 22).

Implications for Wage Differentials The evidence on productivity presented above, combined with the results in Tables 1 through 3, suggests that foreign investment is associated with both productivity and wage increases. Increased foreign investment raises productivity, and the resulting benefits to the firm are shared with its employees in the form of higher wages. However, those productivity and wage increases are diffused to domestic enterprises only in the case of the United States. One implication is that wage differentials between foreign and domestic enterprises should exist in both Mexico and Venezuela, but should be dissipating over time in the United States. With rapid turnover, workers in foreign enterprises should have transmitted their human capital to other enterprises, resulting in an aggregate increase in wages across both domestic and foreign enterprises. Below, we explore the extent of wage differentials between foreign and domestic enterprises in Mexico, Venezuela, and the United States.

\section{Comparing Wages in Domestic and Foreign Enterprises}

With high turnover or rapid rates of technological diffusion between foreign and domestic enterprises, wage differentials between foreign and domestic enterprises should become (over time) quite small. From this perspective, high wage differentials could reflect the lack of spillovers between foreign and domestic enterprises. Other possibilities, consistent with observed wage differentials, is that higher 
foreign wages are due to characteristics other than foreignness per se--such as plant size, location, type of industry, or skill mix. We explore these possibilities below. Even after controlling for these characteristics, wage differentials between foreign and domestic enterprises persist in Mexico and Venezuela, but become quite small in the United States. These results are consistent with evidence on wage spillovers from foreign investment in the United States but a lack of wage spillovers in the two developing countries.

Cross-Section Comparisons We begin with a cross-section comparison of wages in domestic and foreign-owned enterprises in the three countries since time series data are not available for the United States. Since the most detailed data for the United States are available only for 1987, we have chosen similar years for Venezuela (1987) and Mexico (1990). In our wage comparisons, we hope to understand the extent to which differences across foreign and domestic firms are due to differences in industry composition, geographic location, and skill levels of employees.

In the US case, establishments are defined as foreign owned if the foreign equity share is 10 per cent or more. To enable us to make comparisons across countries, in this section we adopt the same definition of foreign owned establishments for Mexico and Venezuela.

Table 4 compares wages across domestic and foreign establishments. In all three countries, manufacturing wages in foreign-owned establishments are higher than in domestically-owned establishments by a factor of 30 per cent. If we compare total compensation, which includes benefits, the ratios are somewhat similar (total compensation was not available for the US). For Mexico and Venezuela, we also examine wage differentials for skilled and unskilled workers. The foreign wage premium is fairly consistent for both skilled and unskilled workers, which suggests that higher wages paid by foreign firms in those two countries are largely not explainable by a different skill mix of workers in foreign-owned firms. Table 4 also shows that the compensation differential stays almost the same if we use total compensation instead of wages to compare foreign and domestic firms. Since total compensation 
is not available for the US in 1987, in the remainder of this section we focus on only on wage differentials (excluding benefits) between foreign and domestic firms.

Impact of Industry Composition We can ask how much of these differences is "explained" by differences in the industry composition of foreign and domestically-owned plants. How much difference would remain if foreign-owned plants were in the same industries as domestically-owned plants (domestic weights) or domestically-owned plants were distributed in the same way as foreign-owned plants (foreign weights), with no changes in the wage levels? We can compute the answer to this question by computing relative wages (foreign/domestic) at the sector level, then calculating a weighted average wage across sectors. The weighted average is computed two ways: using the foreign and the domestic distribution of employment across sectors. If foreign and domestic wages are equal within sectors, and differences between foreign and domestic wages are due only to different industry mix among domestic and foreign firms, our weighted mean ratio of foreign to domestic wages should be close to unity.

The results are reported in Table 5. Since the wage differential for all three countries remains far from zero, industry mix cannot provide the whole explanation for the wage differential. In the US, about half of the aggregate difference in manufacturing compensation per worker, but a smaller share outside of manufacturing, can be accounted for by industry distribution. In Mexico, over two thirds of the wage differential can be explained by industry distribution, while in Venezuela only one third of the wage difference is explained by industry composition.

The impact of industry-mix on aggregate wage differentials can also be explored by asking how average wages would compare in foreign and domestic plants if they paid the same wages within each industry but differed only in industry composition. We recalculated average domestic wages by sector, and then derived a weighted foreign and domestic wage using foreign and domestic weights respectively. The resulting ratio of foreign to domestic wages captures pure differences in industry composition across both sets of firms, since within the same industry, we assume that both sets of firms pay the same wages. 
The impact of industry composition is given in another way in Table 6 . In the US, the industry composition of employment led to higher pay in foreign-owned plants, by margins of about 7 per cent in both manufacturing and non-manufacturing. However, foreign affiliates were much more concentrated in the relatively high-wage manufacturing sector than were domestically-owned firms (41 per cent against 21 per cent). That difference added another 7 per cent or so to the aggregate wage differential. This suggests that in the United States, half of the industry-mix effect reflected differences in compensation within manufacturing and non-manufacturing, while half reflected the greater concentration of foreign affiliates in manufacturing, a fairly high-wage sector.

The results for Mexico and Venezuela for manufacturing alone are quite different from those for the United States. For these two countries, differences in industry composition for foreign and domestic firms account for higher wage margins of 5.8 (Mexico) and 13.6 (Venezuela) per cent. This suggests that only 20 to 30 per cent of the aggregate wage differential can be explained by a different composition of foreign and domestic firms. Although Table 6 does indicate that foreign firms are located in higher wage sectors, it also shows that this is only a small part of the explanation. To the extent that foreign investment also affects domestic wages positively, the results in Table 6 are also likely to overstate the importance of industry composition. What could appear to be the attraction of foreign investors for high wage sectors could in fact be an outcome of high levels of foreign investment.

Location of Foreign Affiliates Another possible explanation for differences in wages between foreign-owned and domestically-owned establishments could be the geographic location of foreign-owned affiliates. If, for example, foreign firms were more likely to be located in high-wage states or regions within any given industry, they might pay higher wages in each industry on average even if within each state they paid exactly the same amount as domestically-owned firms and therefore were presumably hiring an equally skilled labor force. Or location in high-wage states might offset and obscure a tendency to hire less skilled workers. Thus, ignoring the location of foreign affiliates might mislead an observer 
into mistaking location effects for differences in average skills employed by foreign affiliates or in the prices they pay for any given skills. This would not be an issue with completely integrated and perfectly competitive labor markets across states and regions, but that would be a strong assumption to make.

To remove possible location effects, we have calculated ratios of affiliate to domestic firm wages per worker at the two-digit (USA) and four-digit (Mexico, Venezuela) level in each state, and then weighted these ratios by the state-industry composition of affiliate employment and domestic firm employment. That procedure can be interpreted as assuming, in effect, that each state is a competitive labor market. The weighted ratios are given in Table 7 .

In the US case, geographic location cannot account for the observed wage differential between foreign and domestic enterprises. Foreign firms pay six or seven per cent more than domestic firms in manufacturing, as compared with the four or five per cent reported in Table 5, where location is ignored. The difference is even greater in non-manufacturing industries where foreign firms pay 12 to 15 per cent more. The lower differential in Table 5 than in Table 7 for manufacturing suggests that in the United States, foreign enterprises tend to locate in low-wage states within each industry. Ignoring location may result in some understatement of the degree to which foreign affiliates pay higher compensation to workers than domestic firms.

In Mexico, location appears to explain less than fifty per cent of the observed wage differential, but unlike the US case, it does appear that foreign enterprises are more likely to locate in higher wage regions. This tendency is even stronger in Venezuela: the fact that foreign enterprises tend to operate in high-wage regions accounts for as much as two-thirds of the observed wage differential between foreign and domestic enterprises.

Impact of Establishment Size in Manufacturing Foreign-owned manufacturing plants are typically much larger than domestic enterprises, both in the United States and abroad (see, for example, Howenstine and Zeile (1994) on the US; Lipsey and Swedenborg (1981) on Sweden; and Blomström 
(1989) on Mexico. Since larger firms also tend to pay higher wages, the foreign-domestic wage differential could be related to the larger size of foreign-owned enterprises. For the United States, there appears to be no difference between foreign and domestic wages after controlling for the size of the plant, in a regression across industries with observations for both foreign and domestic plants. The results are reported in Table 8. Independent variables included physical capital intensity (defined as the nonemployee compensation share of value-added), plant size or scale (defined as average value-added per establishment), and a dummy variable for foreign ownership.

In Mexico, however, differences between foreign and domestic wages persist after controlling for both size (plant scale) and capital intensity. Higher wages in foreign establishments are most significant for skilled workers, although the difference in wages remains (barely) significant for unskilled workers as well.

Whether one considers size of establishment as an explanation for wage differences depends partly on the purpose of the analysis. If one wishes to know whether production functions or technology differ between foreign-owned and domestically-owned establishments, size of output is clearly an essential variable. For a judgment about labor market impacts of foreign investment, the relevance of size is not as clear, partly because the reason for the correlation between size of establishment and wage rates is not obvious. If a host country wishes to decide about the desirability of inward foreign direct investment, and if such investments are typically associated with large size relative to domestic establishments, it should not matter to the host country whether any benefits stem from foreignness or from size.

\section{Time-Series Comparisons (Venezuela Only)}

One shortcoming of the cross-section comparisons above is that we cannot control jointly for differences in industry composition, size, and capital intensity. Controlling for all these effects concurrently would require a time series, which we only have for Venezuela and Mexico. In Table 9, 
we report the wage differentials between foreign and domestic establishments for Venezuela, after controlling for industry effects, size, and capital intensity. These results essentially compare wages across firms within the same industry, plant size, and capital labor ratio.

The results show that wage differentials persist after controlling for all these factors, although the wage differential falls from 50 per cent (no controls) to between 16 and 18 per cent after including the controls. The wage differential seems to remain whether the foreign affiliate has majority or minority foreign ownership.

\section{Concluding Remarks}

This paper explores the relationship between wages and foreign investment in Mexico, Venezuela, and the United States. Despite very different economic conditions and levels of development, we find one fact which is robust across all three countries: higher levels of foreign investment are associated with higher wages. However, in Mexico and Venezuela, foreign investment was associated with higher wages only for foreign-owned firms--there is no evidence of wage spillovers leading to higher wages for domestic firms. In the United States the evidence is much stronger in favor of wage spillovers.

The lack of spillovers in Mexico and Venezuela is consistent with significant wage differentials between foreign and domestic enterprises. These wage differentials persist after controlling for size, geographic location, skill mix, and capital intensity. These wage differences, together with productivity differences, are consistent with greater human capital formation in foreign firms and lower turnover. Future research will examine the extent to which these wage differentials can be explained by lower turnover in foreign enterprises. In the United States, where the evidence suggests wage spillovers from foreign to domestic enterprises, wage differentials are smaller. In fact, a large part of the wage differential seems to disappear after accounting for the fact that foreign-owned enterprises are larger and more capital intensive than their domestic counterparts. The smallness of the wage differential, combined 
with wage spillovers from foreign to domestic enterprises, is consistent with knowledge spillovers from foreign to domestic enterprises in the United States. 


\section{References}

Aitken, Brian and Ann Harrison. 1993. "Does Proximity to Foreign Firms Induce Technology Spillovers?", PRD Working Paper, World Bank.

Blomström, Magnus. 1989. Foreign Investment and Spillovers, London and New York, Routledge.

Caves, Richard. 1982. Multinational Enterprise and Economic Analysis Cambridge University Press.

Eaton, Jonathan, and Samuel Kortum. 1994. "The Internationalization of U.S. Patenting." NBER-CEPR International Seminar on International Trade (ISIT). October 1994.

Germidis, Dimitri. 1977. Transfer of Technology by Multinational Corporations, Paris, Development Center of the OECD.

Globerman, Steven. 1979. "Foreign Direct Investment and 'Spillover' Efficiency Benefits in Canadian Manufacturing Industries," Canadian Journal of Economics, February.

Goncalves, R. 1986. "Technological Spillovers and Manpower Training: A Comparative Analysis of Multinational and National Enterprises in Brazilian Manufacturing", Journal of Development Economics, XI July.

Grossman, Gene and Elhanan Helpman. 1991 a. "Quality Ladders and Product Cycles", Quarterly Journal of Economics, 106, 557-586.

Grossman, Gene and Elhanan Helpman. 1991b. "Innovation and Growth in the Global Economy", Cambridge, MIT Press.

Haddad, M. and Ann Harrison. 1993. "Are There Positive Spillovers from Direct Foreign Investment? Evidence from Panel Data for Morocco", Journal of Development Economics, October.

Harrison, Ann. 1993. "Foreign Investment in Three Developing Countries: Determinants and Consequences", in M. Roberts and J. Tybout, forthcoming.

Helleiner, G.K. 1989. "Transnational Corporations and Foreign Direct Investment", in Hollis Chenery and T.N. Srinivasan, Handbook of Development Economics, Vol II, C. 27.

Howenstine, Ned G. and William J. Zeile. 1994. "Characteristics of Foreign-Owned U.S. Manufacturing Establishments", Survey of Current Business, Vol. 74, No.1, January, pp. 34-59.

Kokko, Ari. 1994. "Technology, Market Characteristics, and Spillovers", Journal of Development Economics, Vol 43, No. 2, April.

Lipsey, Robert E. 1995. "Foreign-Owned Firms and U.S. Wages", Report to the U.S. Department of Labor.

Lipsey, Robert E. and Birgitta Swedenborg. 1981. "Foreign Takeovers of Swedish Firms," NBER Working Paper No. 641. 
Lucas, Robert. 1993. "Making a Miracle", Econometrica, Vol 61, Number 2, March, 251-272.

Luttmer, E. and D. Oks. 1993. "Productivity in Mexican Manufacturing Industries", World Bank, 1993.

Mody, A., J. Sanders, R. Suri, C. Rao, F. Contreras. 1991. "International Competition in the Bicycle Industry", World Bank.

Reuber, Grant L. 1973. Private Foreign Investment in Development, Clarendon Press, Oxford.

Rhee, Y.W. and T. Belot. 1989. "Export Catalysts in Low-Income Countries", World Bank Discussion Paper No. 72.

Romer, Paul. 1993. "Idea Gaps and Object Gaps in Economic Development", Journal of Monetary Economics 32, 543-573.

U.S. Bureau of the Census. 1990. 1988 Annual Survey of Manufactures, Washington, D.C., U.S. Government Printing Office.

Government Printing Office.

1992. 1990 Annual Survey of Manufactures, Washington, D.C., U.S

U.S. Department of Commerce. 1992. Foreign Direct Investment in the United States: Establishment Data for 1987, Bureau of Economic Analysis and Bureau of the Census, June, Washington, D.C., Government Printing Office.

1993. Foreign Direct Investment in the United States, Establishment Data for Manufacturing, 1990, Bureau of Economic Analysis and Bureau of the Census, August, Washington, D.C., Government Printing Office.

. 1994a. Foreign Direct Investment in the United States, Establishment Data for Manufacturing, 1988, Bureau of Economic Analysis and Bureau of the Census, May, Washington, D.C., Government Printing Office.

. 1994b. Foreign Direct Investment in the United States, Establishment Data for Manufacturing, 1991, Bureau of Economic Analysis and Bureau of the Census, September, Washington, D.C., Government Printing Office. 
Table 1: The Relationship Between Foreign Direct Investment and

Manufacturing Industry Wages in Mexico and Venezuela

Dependent Variable: Log Wage (W)

\begin{tabular}{|c|c|c|c|c|c|c|c|c|}
\hline & \multicolumn{4}{|c|}{ Venezuela } & \multicolumn{4}{|c|}{ Mexico } \\
\hline & \multicolumn{2}{|c|}{ All Enterprises } & \multicolumn{2}{|c|}{ Domestic Only } & \multicolumn{2}{|c|}{ All Enterprises } & \multicolumn{2}{|c|}{ Domestic Only } \\
\hline & $\begin{array}{c}\text { Sk } \\
\text { Wages }\end{array}$ & $\begin{array}{c}\text { Usk } \\
\text { Wages }\end{array}$ & $\begin{array}{c}\text { Sk } \\
\text { Wages }\end{array}$ & $\begin{array}{c}\text { Usk } \\
\text { Wages }\end{array}$ & $\begin{array}{c}\text { Skl } \\
\text { Wages }\end{array}$ & $\begin{array}{c}\text { Usk } \\
\text { Wages }\end{array}$ & $\begin{array}{c}\text { Sk } \\
\text { Wages }\end{array}$ & $\begin{array}{c}\text { Usk } \\
\text { Wages }\end{array}$ \\
\hline DFI & $\begin{array}{l}0.287 \\
(5.8)\end{array}$ & $\begin{array}{l}0.220 \\
(6.4)\end{array}$ & $\begin{array}{c}-0.166 \\
(3.2)\end{array}$ & $\begin{array}{c}-0.142 \\
(4.0)\end{array}$ & $\begin{array}{l}0.215 \\
(10.3) \\
\end{array}$ & $\begin{array}{c}0.033 \\
(2.1) \\
\end{array}$ & $\begin{array}{c}-0.055 \\
(1.4)\end{array}$ & $\begin{array}{c}0.024 \\
(0.8)\end{array}$ \\
\hline KSTOCK & $\begin{array}{l}0.111 \\
(40.0)\end{array}$ & $\begin{array}{l}0.069 \\
(39.9)\end{array}$ & $\begin{array}{l}0.109 \\
(38.5)\end{array}$ & $\begin{array}{l}0.069 \\
(38.9)\end{array}$ & $\begin{array}{l}0.080 \\
(23.8)\end{array}$ & $\begin{array}{l}0.060 \\
(23.4)\end{array}$ & $\begin{array}{l}0.079 \\
(19.1)\end{array}$ & $\begin{array}{l}0.053 \\
(17.5)\end{array}$ \\
\hline ROYALTY & $\begin{array}{c}2.117 \\
(5.6)\end{array}$ & $\begin{array}{c}0.682 \\
(2.6)\end{array}$ & $\begin{array}{l}1.340 \\
(3.5)\end{array}$ & $\begin{array}{l}0.554 \\
(2.0)\end{array}$ & $\begin{array}{l}1.884 \\
(5.0)\end{array}$ & $\begin{array}{l}1.455 \\
(5.2)\end{array}$ & $\begin{array}{c}2.129 \\
(3.3)\end{array}$ & $\begin{array}{l}1.522 \\
(3.5)\end{array}$ \\
\hline $\begin{array}{l}\text { OUTPUT } \\
\text { PRICE }\end{array}$ & $\begin{array}{c}0.019 \\
(0.7) \\
\end{array}$ & $\begin{array}{c}-0.019 \\
(1.0) \\
\end{array}$ & $\begin{array}{l}0.037 \\
(1.3) \\
\end{array}$ & $\begin{array}{c}-0.013 \\
(0.7) \\
\end{array}$ & $\begin{array}{l}0.115 \\
(2.4) \\
\end{array}$ & $\begin{array}{l}0.112 \\
(3.1) \\
\end{array}$ & $\begin{array}{c}0.070 \\
(1.2) \\
\end{array}$ & $\begin{array}{c}0.084 \\
(2.0) \\
\end{array}$ \\
\hline $\begin{array}{l}\text { REGION } \\
\text { PRICE }\end{array}$ & $\begin{array}{c}0.065 \\
(0.6) \\
\end{array}$ & $\begin{array}{c}-0.275 \\
(3.7) \\
\end{array}$ & $\begin{array}{c}0.0658 \\
(0.6)\end{array}$ & $\begin{array}{c}-0.254 \\
(3.4) \\
\end{array}$ & -- & -- & -- & -- \\
\hline $\begin{array}{l}\text { Industry } \\
\text { Dummies }\end{array}$ & Yes & Yes & Yes & Yes & Yes & Yes & Yes & Yes \\
\hline $\begin{array}{l}\text { Region } \\
\text { Dummies }\end{array}$ & Yes & Yes & Yes & Yes & Yes & Yes & Yes & Yes \\
\hline $\begin{array}{l}\text { Year } \\
\text { Dummies }\end{array}$ & Yes & Yes & Yes & Yes & Yes & Yes & Yes & Yes \\
\hline $\mathrm{N}$ & 10870 & 12322 & 10793 & 12263 & 4717 & 4726 & 3650 & 3664 \\
\hline R-Square & 0.47 & 0.44 & 0.44 & 0.41 & 0.50 & 0.56 & 0.46 & 0.53 \\
\hline
\end{tabular}

Notes: T-statistics in parentheses. 
Table 2: The Relationship Between Foreign Direct Investment and Manufacturing Industry Wages in Venezuela and Mexico: Two-Stage Least Squares Estimates

Dependent Variable: Log Wage (W)

\begin{tabular}{|c|c|c|c|c|}
\hline & \multicolumn{4}{|c|}{ Coefficient on Foreign Investment } \\
\hline & \multicolumn{2}{|c|}{ 2SLS (1) } & \multicolumn{2}{|c|}{$2 S L S(2)$} \\
\hline & $\begin{array}{l}\text { Skilled } \\
\text { Wages }\end{array}$ & $\begin{array}{c}\text { Unskilled } \\
\text { Wages }\end{array}$ & $\begin{array}{l}\text { Skilled } \\
\text { Wages }\end{array}$ & $\begin{array}{c}\text { Unskilled } \\
\text { Wages }\end{array}$ \\
\hline \multicolumn{5}{|l|}{ Venezuela } \\
\hline All Enterprises & $\begin{array}{c}6.829 \\
(6.0)\end{array}$ & $\begin{array}{c}2.949 \\
(4.5)\end{array}$ & $\begin{array}{c}4.077 \\
(5.5)\end{array}$ & $\begin{array}{l}1.982 \\
(4.1)\end{array}$ \\
\hline Domestic Only & $\begin{array}{c}-2.964 \\
(1.5)\end{array}$ & $\begin{array}{c}-0.266 \\
(0.3)\end{array}$ & $\begin{array}{c}-0.553 \\
(.5)\end{array}$ & $\begin{array}{l}.726 \\
(0.8)\end{array}$ \\
\hline \multicolumn{5}{|l|}{ Mexico } \\
\hline All Enterprises & $\begin{array}{c}0.197 \\
(8.7)\end{array}$ & $\begin{array}{c}0.016 \\
(0.9)\end{array}$ & $\begin{array}{c}0.182 \\
(7.9)\end{array}$ & $\begin{array}{c}0.013 \\
(0.7)\end{array}$ \\
\hline Domestic Only & $\begin{array}{c}-0.060 \\
(1.4)\end{array}$ & $\begin{array}{l}0.027 \\
(0.9)\end{array}$ & $\begin{array}{c}-0.057 \\
(1.4)\end{array}$ & $\begin{array}{c}0.024 \\
(0.8)\end{array}$ \\
\hline
\end{tabular}

Notes: T-statistics in parentheses.

(1) Instruments for DFI include US wages by SIC industry, the US labor share in value added (by SIC) and the US labor share in output.

(2) Instruments for DFI include all those described in (1), plus the distribution of foreign investment in Mexico (for Venezuela), the distribution of foreign investment in Venezuela (for Mexico), import penetration, and the share of foreign investment in the region for all other manufacturing sectors. 
Table 3: The Relation Between Foreign Direct Investment and Wages in the United States 1987: Cross-State Regressions

Dependent Variable: Average Wage (by Industry and State)

\begin{tabular}{|c|c|c|}
\hline & $\begin{array}{l}\text { Wages in All } \\
\text { Establishments }\end{array}$ & $\begin{array}{c}\text { Wages in Domestic } \\
\text { Establishments }\end{array}$ \\
\hline $\mathrm{DFI}^{\mathrm{a}}$ & $\begin{array}{c}37.192 \\
(11.1)\end{array}$ & $\begin{array}{c}34.368 \\
(10.3)\end{array}$ \\
\hline STATE WAGE LEVEL ${ }^{b}$ & $\begin{array}{c}3.564 \\
(2.4)\end{array}$ & $\begin{array}{l}3.457 \\
(1.4)\end{array}$ \\
\hline INDUSTRY WAGE LEVEL ${ }^{b}$ & $\begin{array}{c}9.379 \\
(2.3)\end{array}$ & $\begin{array}{l}9.547 \\
(4.2)\end{array}$ \\
\hline $\mathbf{N}$ & 1091 & 1091 \\
\hline R-Square & 0.12 & 0.11 \\
\hline
\end{tabular}

Note: $\mathrm{T}$-statistics in parentheses.

${ }^{\text {a} E m p l o y m e n t ~ i n ~ f o r e i g n-o w n e d ~ e s t a b l i s h m e n t s ~ a s ~ p e r ~ c e n t ~ o f ~ t o t a l ~ e m p l o y m e n t ~ i n ~ t h a t ~ i n d u s t r y ~ i n ~ t h a t ~}$ state.

b $_{\text {For definition, see text. }}$ 
Table 4: Comparing Wages in Domestic and Foreign Establishments:

Mexico, Venezuela, and the United States

\begin{tabular}{|c|c|c|}
\hline & Wages & Wages and Benefits \\
\hline \multicolumn{3}{|c|}{ Mexico (1990) } \\
\hline Manufacturing (All) & 1.32 & 1.38 \\
\hline Skilled Labor & 1.32 & 1.38 \\
\hline Unskilled Labor & 1.30 & -- \\
\hline \multicolumn{3}{|c|}{ Venezuela (1987) } \\
\hline Manufacturing (All) & 1.31 & 1.31 \\
\hline Skilled Labor & 1.21 & 1.21 \\
\hline Unskilled Labor & 1.25 & 1.25 \\
\hline \multicolumn{3}{|c|}{ United States (1987) } \\
\hline Manufacturing & 1.29 & -- \\
\hline Non-Manufacturing & 1.12 & -- \\
\hline Total Industry & 1.29 & -- \\
\hline
\end{tabular}


Table 5: Wages per Worker, Foreign/Domestic Ratio With Industries Weighted Identically

\begin{tabular}{||c|c|c||}
\hline \hline Host Country & \multicolumn{2}{|c|}{ Weights } \\
\hline & Foreign & Domestic \\
\hline Mexico (1990), Manufacturing & 1.30 & 1.12 \\
\hline Venezuela (1987), Manufacturing & 1.22 & 1.19 \\
\hline United States (1987) & & 1.05 \\
\hline Manufacturing & 1.04 & 1.18 \\
\hline Non-Manufacturing & 1.12 & 1.14 \\
\hline All Industries & 1.10 & \\
\hline
\end{tabular}

Table 6: Impact of Industry Composition on Wage Per Worker in Foreign and Domestically Owned Establishments

\begin{tabular}{||c|c|}
\hline Host Country & Foreign/Domestic Wages \\
\hline Mexico, Manufacturing & 1.06 \\
\hline Venezuela, Manufacturing & 1.14 \\
\hline United States & \\
\hline Manufacturing & 1.07 \\
\hline Non-Manufacturing & 1.07 \\
\hline All Industries & 1.14 \\
\hline
\end{tabular}


Table 7: Impact of Geographic Location on Wage Per Worker in Foreign and Domestically Owned Establishments

\begin{tabular}{||c|c|c||}
\hline \hline Host Country & \multicolumn{2}{|c|}{ Weights } \\
\hline & Foreign & Domestic \\
\hline Mexico (1990), Manufacturing & 1.260 & 1.160 \\
\hline Venezuela (1987), Manufacturing & 1.140 & 1.122 \\
\hline United States (1987) & & 1.062 \\
\hline Manufacturing & 1.071 & 1.117 \\
\hline Non-Manufacturing & 1.149 & 1.103 \\
\hline All Industries & 1.120 & \\
\hline
\end{tabular}

Table 8: Impact of Plant Size on Wages in Foreign-owned and Domestically-owned Manufacturing Establishments

Dependent Variable: Wage per Worker

\begin{tabular}{||c|c|c|c|c||}
\hline $\begin{array}{c}\text { Independent } \\
\text { Variables }\end{array}$ & US & \multicolumn{3}{|c|}{ Mexico } \\
\hline \hline & All & Skilled & Unskilled & All \\
\hline \hline Plant Size & $\begin{array}{c}0.07 \\
(11.35)\end{array}$ & $\begin{array}{c}0.04 \\
(6.42)\end{array}$ & $\begin{array}{c}0.01 \\
(5.62)\end{array}$ & $\begin{array}{c}0.02 \\
(5.05)\end{array}$ \\
\hline Capital Intensity & $\begin{array}{c}0.59 \\
(0.90)\end{array}$ & $\begin{array}{c}1.56 \\
(0.70)\end{array}$ & $\begin{array}{c}-0.42 \\
(0.47)\end{array}$ & $\begin{array}{c}0.95 \\
(0.64)\end{array}$ \\
\hline Foreign Dummy & $\begin{array}{c}-0.09 \\
(-0.43)\end{array}$ & $\begin{array}{c}3.78 \\
(3.78)\end{array}$ & $\begin{array}{c}0.56 \\
(1.43)\end{array}$ & $\begin{array}{c}2.03 \\
(3.07)\end{array}$ \\
\hline $\mathrm{N}$ & 624 & 239 & 239 & 239 \\
\hline R-Square & 0.21 & 0.24 & 0.13 & 0.17 \\
\hline
\end{tabular}

Notes: T-statistics in parentheses. Results for the United States taken from Howenstine and Zeile (1994). 
Table 9: Time Series Comparisons of Wages Paid by Foreign and Domestic Manufacturing Establishments in Venezuela (Coefficient on Foreign Ownership Dummy)

Dependent Variable: Log Wage of Skilled Workers $(\mathrm{N}=41121)$

\begin{tabular}{|c|c|c|c|}
\hline & Foreign Share $>=50 \%$ & Foreign Share $<50 \%$ & R-Square \\
\hline No Controls & $\begin{array}{l}0.489 \\
(23.2)\end{array}$ & $\begin{array}{l}0.513 \\
(34.3) \\
\end{array}$ & 0.09 \\
\hline $\begin{array}{l}\text { Controlling for } \\
\text { 2-digit SIC }\end{array}$ & $\begin{array}{l}0.465 \\
(22.5)\end{array}$ & $\begin{array}{l}0.474 \\
(32.3)\end{array}$ & 0.14 \\
\hline $\begin{array}{l}\text { Controlling for } \\
\text { 4-digit SIC }\end{array}$ & $\begin{array}{l}0.377 \\
(18.7)\end{array}$ & $\begin{array}{l}0.387 \\
(26.8)\end{array}$ & 0.19 \\
\hline $\begin{array}{l}\text { Controlling for Size } \\
\text { and 4-digit SIC }\end{array}$ & $\begin{array}{l}0.179 \\
(9.8)\end{array}$ & $\begin{array}{l}0.158 \\
(11.6)\end{array}$ & 0.35 \\
\hline $\begin{array}{l}\text { Controlling for Size, } \\
\text { Capital/Labor Ratio, } \\
\text { and 4-digit SIC }\end{array}$ & $\begin{array}{c}0.179 \\
(9.8)\end{array}$ & $\begin{array}{l}0.157 \\
(11.7)\end{array}$ & 0.35 \\
\hline
\end{tabular}

Notes: T-statistics in parentheses. All regressions include annual time dummies. 